\title{
TOWARDS A PRACTICAL AND EMPIRICALLY GROUNDED ACCOUNT OF ÚTANG-NA-LOÓB AS A FILIPINO VIRTUE
}

\author{
Jacklyn A. Cleofas \\ Ateneo de Manila University \\ jcleofas@ateneo.edu
}

\begin{abstract}
Although there are existing philosophical accounts of útang-na-loób (debt of good will) and the suggestion that this Filipino cultural practice can be considered a virtue is not new, questions remain about how morally desirable forms of útang-na-loób can be separated from its problematic involvement in nepotism, patronage politics, life-long servitude, corruption, and other forms of injustice. In this paper, I develop a practical and empirically grounded account of útang-na-loób as a Filipino virtue by using a neo-Aristotelian framework that allows for the incorporation of research from the social sciences into virtue-theoretic recommendations for action. I argue that útang-na-loób must be understood in conjunction with a distinctly Filipino understanding of justice (katarúngan), especially on what counts as fair distribution of resources and opportunities, to promote culturally rooted social harmony (pagkakáisá) and communal flourishing. The paper ends with a brief discussion of a case to demonstrate how útang-na-loób can be lived out in a morally desirable way.
\end{abstract}

\section{Keywords}

applied ethics; Filipino philosophy; justice; Marxist objection to virtue

\section{About the Author}

Jacklyn A. Cleofas (National University of Singapore, Ph.D.) is Assistant Professor of Philosophy at the Ateneo de Manila University. She works on topics in moral psychology, metaethics, and virtue epistemology. Some of her recent papers have been published or will be published in Journal of Catholic Social Thought, Perspectives in the Arts and Humanities Asia, and Frontiers of Philosophy in China. 


\section{INTRODUCTION}

Uttang-na-loób is a Filipino practice that is associated with good and bad actions. On the one hand, filial devotion to ageing parents, who have devoted much of their lives to members of the family, is usually taken as a prime example of the practice. On the other, we often hear of political leaders who are beholden to their benefactors to the point of brazenly disregarding the welfare of the entire nation. In this paper, I argue that we need a better account of útang-na-loób as a Filipino virtue because there are several things missing from existing philosophical accounts of the practice. ${ }^{1}$ To develop an improved account of this Filipino virtue we need to use a framework that is adaptable to specific cultural contexts and allows for a principled exclusion of forms of the practice that lead to nepotism, corruption, and many other types of morally undesirable behavior. In my view, Martha Nussbaum's neo-Aristotelian framework satisfies these requirements.

In the next two sections, I dwell on the reason we need an improved account of útang-na-loób as a virtue: (a) existing accounts are not empirically grounded, ${ }^{2}$ sufficiently action-guiding, or integrated with considerations connected to justice; and (b) problematic instantiations of the practice abound such that we need a principled reason for setting these aside. In the fourth section, I discuss Nussbaum's framework and show that it is well-suited for developing an ideal account of útangna-loób. After applying the neo-Aristotelian framework to the Filipino virtue, a case discussion is provided to illustrate how útang-na-loób should be lived out in practical contexts.

Some brief comments on the translation of the central term and the concept of virtue are in order before our discussion begins. To bring forward the discussion initiated by other philosophers, I adopt existing translations of terms whenever possible. For instance, I use Leonardo de Castro's rendering of útang-na-loób as "debt of good will," which stems from his insight about the primacy of conation in the very rich term loób and the connection between útang-na-loób and kagandáhang-loób, which he translates as good will. My discussion also recognizes the importance of good will and benevolence for understanding útang-na-loób. But unlike de Castro, I do not focus on kagandáhang-loób. In general terms, virtue is a morally desirable character trait or disposition that involves excellent patterns of choice, motivation, and behavior in some specific aspect of human life. Here trait or disposition is understood as an acquired and enduring property of the person that is intimately connected with her very identity. For instance, possessing courage as a virtue means having traits or dispositions that manifest excellent patterns of choice, motivation, and behavior regarding fear, such that one is neither excessive nor deficient in responding to it. ${ }^{3}$ 


\section{A BRIEF REVIEW OF TWO PHILOSOPHICAL ACCOUNTS OF ÚTANG-NA-LOÓB}

De Castro and Jeremiah Reyes develop distinct philosophical accounts of útangna-loób. For de Castro, útang-na-loób is the right response to an act of good will (kagandáhang-loób), which is a freely bestowed act of benevolence towards someone experiencing extreme need. He identifies three necessary conditions for an act to convey kagandáhang-loób: (1) the act is done out of the benefactor's own initiative (kusâng loób) and not from any external compulsion; (2) the act is motivated by positive emotions such as charity or sympathy for the beneficiary; (3) the act is not motivated by the expectation or anticipation of reward (de Castro, "Debt of Good Will"). The first condition features a positive normative evaluation of the action, which acquires moral worth because it is not done out of self-interest or some external compelling force. The second condition crucially implies a conception of the will associated with morally desirable emotions rather than pure reason. One who performs an act of good will does so from a feeling of personal connection with a needy individual and a deeply felt desire to alleviate her suffering. The third condition creates a puzzle about why the beneficiary of the action acquires a sense of indebtedness to her benefactor. If the latter is not motivated by any anticipation of reward or any expectation of being repaid, why is there any sense of indebtedness at all?

De Castro solves the foregoing puzzle in a very astute way; his solution can be summed up as follows:

1. Since the benefactor is motivated by a desire to help and not by any desire for reward, she does not have a right to reciprocal treatment in the manner of an ordinary debt or being owed a favor.

2. However, this does not mean that the beneficiary is thereby free from any obligation towards the benefactor.

3. The beneficiary creates a self-imposed obligation, precisely a debt of good will, toward the benefactor. She compels herself not just to "return the favor," something that implies a possible termination of indebtedness, but to make her own act of good will toward her benefactor. In this way, the beneficiary becomes a benefactor herself and a relationship of mutual dependence and good will is created.

Here, de Castro brings to light one of the most important features of útang-naloób: ${ }^{4}$ being a responsible beneficiary of another's act of good will. Below I discuss how consciously owning a self-imposed obligation to one's benefactor enables a 
person, who repays a debt of good will, to put an emphasis on her agency instead of her neediness.

Before moving on to Reyes's discussion of útang-na-loób, let us take note of one important claim from de Castro. He says that útang-na-loób is distinct from and not reducible to interpersonal justice. I take him to mean that interpersonal justice involves a dimension of exactness and calculative thinking that is at odds with útang$n a-l o o ́ b$. While it is true that the latter involves elements that are incompatible with justice, such as significant emotional involvement and lavish giving back, it seems inadvisable to establish a clear separation between útang-na-loób and interpersonal justice. Justice need not be construed in a cold and impersonal way. And insofar as fair distribution of goods is crucial for social harmony and communal flourishing, allocation of resources for repaying debts of good will has important implications for justice. One of the gaps in existing philosophical accounts of útang-na-loób is a detailed discussion on how this cultural practice is connected to the way in which Filipinos understand justice. There is also lack of clarity on the practical mechanics of imposing a debt of good will on oneself and what counts as the appropriate timing and manner of repaying these debts. These gaps are addressed in sections five and six below.

Let us now turn to Reyes, whose main project is to develop a Filipino virtue ethics that is rooted in a Thomist perspective. According to Reyes, Filipino virtue ethics "seeks to preserve and strengthen human relationships" (167). At the same time, he says that Filipino virtues are all in the will (loób). His idea seems to be that excellent moral functioning for Filipinos is a matter of cultivating a relationally oriented will that motivates compassionate behavior towards the needy, with those who receive help being in turn motivated to emulate and repay the benefactor's solicitous care for others. Following Virgilio Enriquez, Reyes identifies oneness or unity (pagkakáisá) as the goal of Filipino virtue ethics (167-168). ${ }^{5}$ Such unity is understood to be something that moves outward from an intimate family setting, to the greater community, onto the entire country, and to the rest of humanity. I take Reyes's claim to imply that the telos of útang-na-loób is oneness with another who is at the same time a benefactor and a beneficiary of one's own act of good will.

Unfortunately, attaining unity with others through the virtue of utang-naloób is not discussed in terms of what counts as an appropriate amount or form of repayment. Reyes mentions but sets aside the Thomist-Aristotelian notion of commutative justice (162). Insofar as commutative justice is based on exact calculations of what is owed, it does not seem to directly apply to útang-na-loób. But from this it does not follow that all and any form of justice is in unconnected with útang-na-loób, not least because allocating goods or opportunities for the benefit of one person can damage others' well-being and harmonious relations 
with the rest of the community. Once again, we see that útang-na-loób must be discussed in connection with justice.

To be fair, Reyes recognizes the need to ensure that útang-na-loób involves a sense of responsibility towards the greater community. He says, "To have utang na loob means that one values kapwa relationships and seeks to prolong and strengthen these relationships" (161). In what follows, I take this idea further by showing that maintenance strong and healthy relationships with others (kápuwâ) requires sustaining a delicate balance between having a particularizing concern for specific others with whom one is closely connected and refraining from excessive attachment to such relationships.

Following Dionisio M. Miranda, Reyes says that the mother-child relationship is the model for útang-na-loób. Maternal concern and solicitude towards those who are weak to the point of being helpless are taken to be motivation for an initial act of good will. A filial response from the child who has benefited from maternal care is then taken as the paradigm example of útang-na-loób. Miranda succinctly puts the point thus: "Maternal love means to insure that the child's love becomes 'maternal'. [...] It means to develop the love of the child so that it becomes itself a source of life" (72). We will go back to this interesting idea in the last section, at this point let us note that specific normative recommendations of living out a maternal responsibility for others are missing.

\section{PROBLEMATIC FORMS OF THE PRACTICE DESCRIBED IN THE SOCIAL SCIENCE LITERATURE}

Saying that útang-na-loób is a virtue implies that it is a form of moral excellence. Previously we have seen that there are some things missing in philosophical accounts that are consistent with this claim. First, there is insufficient discussion of how útang-na-loób is connected to justice. Second, there is not enough practical guidance. Because there are many morally problematic instantiations of the practice, these gaps are especially worrying. In this section, I go over the list of problematic instantiations of útang-na-loób to show how serious these worries are. The following list is derived and extended from the work of Mary Hollnsteiner, who discusses útang-na-loób as a form of reciprocity:

(a) Lack of job security is often addressed by asking favors from powerful people, which creates a debt of good will that is collected during elections. Hollnsteiner gives the example of a family who approaches someone powerful and well-connected to prevent one of their members from being 
laid off (74). After their request is granted, they feel obligated to vote for the congressional candidate associated with their benefactor, regardless of who they really think is best suited for the position. Hollnesteiner notes that politicians who understand the dynamics of útang-na-loób deliberately cultivate debts of goodwill towards themselves so that when election time comes, they can rely on votes being cast in their favor (81-82).

(b) In the absence of strong and sufficient institutional support that provides access to healthcare, efforts to help families with sick members create a kind of útang-na-loób that can never be fully repaid (80). Hollnsteiner says that residents of a Tawiran, a small town in Bulacan, rely on individuals with the skill, knowledge, and connections to get someone admitted and gain access to medicines and medical tests in the crowded government hospitals in Manila. ${ }^{6}$ She notes that the demand for access to hospitalization from ordinary people, such as folk in Tawiran, exceeds efforts to increase the supply of low-cost healthcare such that útang-naloób is generated frequently. Here we see that útang-na-loób functions as a mechanism for sustaining social ties that provide access to basic needs. It becomes a stopgap measure for a systemic problem and may even get in the way of efforts to introduce necessary social and institutional reforms. People who are preoccupied with cultivating social ties and repaying debts of goodwill have less time and energy to work towards the kind of reform that makes universal access to healthcare and education possible. Again, unscrupulous individuals take advantage of the cultural practice for their own ends. For instance, unqualified and ineffective politicians manage to cling to power (in part) through the endowment of scholarships and assistance with medical expenses.

(c) Hollnsteiner reports that her subjects consider being granted a loan by a bank or having official papers processed in an expedited manner as a favor that merits repayment (79). It seems that red tape and inefficiency are so widespread that people feel beholden to officials when they actually get what they need. Giving tokens of gratitude during festive occasions to government and bank officials, especially during the Christmas season, is common. Hollnsteiner rightly notes two things. First, the acceptableness of the gift depends on timing: "the gift is usually presented after the initial service is rendered, sometimes long afterwards and at an appropriate festive occasion. To give before the service is rendered would smack of bribery, while to give shortly after the service would be crass and crude" (79). Second, even with such careful and sensitive timing for gift-giving, it is very easy for officials to rationalize bribery and other forms of corruption as útang-na-loób repayment. 
(d) Útang-na-loób is generated in situations where people have no other recourse to sustain their livelihood except to ask others for special favors. Hollnsteiner describes a form of fishing partnership called lúsong, in which people supply unskilled labor to build a fish trap (72-73). She says that in the 1950 os fisherfolk were already avoiding fishing partnerships because it imposes onerous debts on them. Instead of asking for volunteers for a lúsong, they save up enough money to hire unskilled workers to help them for a day. People who are not very well-off are sometimes prevented from improving their situation by debts of goodwill. Whenever they incur any surplus, there is an expectation of using much of it to repay benefactors. Consequently, some never acquire the kind of financial stability that cushions them from minor accidents or sudden requirements to pay for an infrequent need. The economic cost of sustaining útang-na-loób needs to be discussed if the practice is to be considered a virtue. More specifically, questions on whether and to what extent útang-na-loób sustains economically unjust or oppressive social arrangements must be addressed. Both social scientists and philosophers have described a state of equilibrium where two individuals or groups become bound in a relationship of mutual support and friendship. ${ }^{7}$ But such an equilibrium can only be reached when the participants are roughly equal in terms of being economically well-off. In a situation where large sections of the population live below the poverty line, attaining the ideal kind of equilibrium seems impossible and any effort to live out útang-na-loób ends up sustaining perpetual indigence.

(e) Útang-na-loób in a superordinate-subordinate relationship perpetuates systemic inequality. Hollnsteiner describes situations in which a subordinate and her family almost never acquire sufficient wealth to properly repay debts of goodwill or move out of a disadvantaged social status. The traditional example for the superordinate-subordinate relationship is the one between landowner and tenant farmer; a more recent example might be one between affluent families in cities and their long-term domestic helpers, nannies (yaya), cooks, and drivers. According to Hollnsteiner, subordinates do not feel the usual uneasiness associated with being indebted to a benefactor and unable to make a proper repayment for her generosity (81). It seems that acceptance of the permanent nature of being an insubordinate diffuses what may otherwise be a deeply felt uneasiness over a debt of goodwill. It is worth noting that a problematic understanding of redistribution underlies útang-naloób in a superordinate-subordinate relationship. Both Hollnsteiner and Kaut note that útang-na-loób stabilizes a situation in which there is a large income gap between certain groups in society. Awareness of this 
gap combined with the value of sharing surplus with the needy "enables a person to lodge a claim on a rich man's wealth" (Hollnsteiner 87 ) or even have "the right to ask from those within his social groupings who have such a surplus" (Kaut 261). However, no real structural reform takes effect. Redistribution of wealth never reaches the point which allows many to escape the vicious cycle of poverty. There is then the question of whether útang-na-loób merely functions as a mechanism for placating the poor masses and creating a false consciousness that facilitates the acceptance of being permanently poor and oppressed.

The many and varied problematic instantiations of utang-na-loób show that the way that it is understood and practiced by Filipinos is far from ideal. In many cases, debts of good will impede instead of promote individual and communal flourishing. A proper discussion of útang-na-loób as a moral virtue is then needed, and this account should especially include reference to social justice. But even before any reference to justice is made, let us notice that we can only provide an ideal account of útang-na-loób by addressing the problems that we just saw. At a bare minimum, we can only address problems that we can see clearly, and this is precisely one of the things that social scientific research allows us to do. Philosophical accounts of Filipino practices can make important claims to currency and relevance if they directly address the needs and difficulties of ordinary folk that are described in the literature. Apart from the insightful social scientific description of problems, however, we need a normative framework to formulate good recommendations for action. In the next section, we turn to the neo-Aristotelian framework for this purpose.

\section{A NEO-ARISTOTELIAN FRAMEWORK FOR VIRTUE AND ITS RELEVANCE FOR ÚTANG-NA-LOÓB}

Developing a philosophical account of útang-na-loób that clearly delineates what is virtuous from what is not requires a framework for moral excellence. In this section, I will discuss Nussbaum's neo-Aristotelian account of virtue and its relevance for Filipino virtue ethics. I opt for this framework for the following reasons: (a) it is particularist in a way that allows for sensitivity to unique local practices; (b) it allows for the principled exclusion of some forms of behavior, including ways of practicing útang-na-loób, based on what does not promote inclusive communal flourishing; (c) it has a potential for allowing relevant research in the social sciences to inform philosophical accounts of virtue; and (d) it directly addresses the need to criticize social norms that result in injustice, while at the same time addressing a Marxist objection to virtue. 
According to Nussbaum, the Aristotelian framework for virtue is based on an "objective account of the human good" while at the same time sensitive to the multiplicity of human experience that gives rise to unique local practices and traditions ("Non-Relative Virtues" 631). ${ }^{8}$ The element of objectivity is comprised of two things. First, there are widely shared experiences that humans need to process and make decisions about. These experiences constitute a common ground for all human beings. Second, there are correct ways to process and decide about such experiences based on what will promote flourishing. Nussbaum thinks that human flourishing cannot be specified in arbitrary ways because there are factual constraints on what counts as ideal human functioning. For instance, apart from the requirement to meet basic human needs, there is the requirement to fulfill the need for meaningful social connections. Nussbaum argues that the requirement to move towards greater social inclusivity and understanding rules out practices that exclude individuals or groups based on, say, gender or socio-economic status. There are objective or factual answers to what practices would not promote the flourishing of an inclusive community. For instance, the unity with others (pagkakáisá) that Filipinos aim for cannot be attained when relationships are damaged by grossly unequal distribution of goods and opportunities. Moreover, an abiding concern for the well-being of the collective, the human family as it were, cannot be promoted if many are excessively attached to relationships with particular others.

Nussbaum argues for Aristotelian particularism by saying that the standard of objectivity of this framework is analogous to those that we find in medicine and navigation. In these domains, sound judgment is always indexed on idiosyncratic details of a case, but there are nevertheless correct answers. For instance, diagnosing and administering treatment to a patient requires general knowledge of illnesses and how the human body works, combined with an accurate view of a unique set of symptoms and a correct understanding of how this person responds to certain forms of treatment. Effective treatment depends on correct diagnosis, which is not something relative to this or that medical professional's opinions. In the same way that there are correct answers in medicine, there should be correct ways of theorizing about the Filipino virtue of utang-na-loób. The material point is that the framework allows us to make the ruling that some courses of action are morally undesirable (or wrong), while also accommodating the multiplicity and contextdependence of correct answers. ${ }^{9}$

On the Aristotelian framework, virtue is an enduring dispositional property of a person that is considered a form of moral excellence because it contributes to inclusive communal flourishing. According to Nussbaum, a proper understanding of each specific virtue begins by isolating "a sphere of human experience that figures in more or less any human life, and in which more or less any human being will have to make some choices rather than others, and act in some way rather than 
some other" ("Non-Relative Virtues" 632). Virtues are individuated on the basis of being an excellent response to some specific domain of human life and are brought together by their positive impact on human flourishing. Thus, we can only speak of individual virtues with reference to particular human experiences such as having bodily appetites, needing to distribute limited resources, feeling fear in the face of threat to one's person, and others.

Using this framework to develop an account of útang-na-loób means identifying the basic experiences associated with the practice. From here we can begin to identify what counts as an excellent response to such experiences. Usually philosophers develop ideas on what counts as excellent by drawing out putative intuitions on what it means to respond well or defectively to some specific experience. ${ }^{10}$ But ideas from putative intuitions must be informed, corrected, or even replaced by ideas generated from available evidence. And this is precisely where social scientific literature comes in. It allows us to systematically reflect on what counts as an excellent response to experiences associated with dependence on others by showing us when and how intentions to reciprocate an act of goodwill become distorted by morally undesirable influences. Moreover, the problematic instantiations of útang-na-loób that we saw in the last section enable us to have a better sense of what disrupts social harmony, warps a sense of indebtedness, and negatively impacts the entire community. So we can say that excellence partly consists in preventing such disruption and warping. And because the evidence also affords a clear understanding of the difficulties that people face and the pitfalls to which they often succumb, we can begin to talk about strategies to help individuals and the entire community by focusing on those difficulties and challenges. Nussbaum ends her paper with a quote from Aristotle's Nicomachean Ethics that describes the framework as an "outline sketch" that still needs to be filled out ("Non-Relative Virtues" 643). I propose that a good way to supply what is missing from the outline is to use evidence from the social science literature to supply details on what is undesirable, and therefore defective, because it leads to disharmony and harm for individuals and the community. ${ }^{11}$ Taking this line, we can also identify what is morally desirable, and therefore excellent, because it leads to desirable forms of social harmony and individual flourishing.

Applying the Aristotelian framework to the case of útang-na-loób means (1) isolating and examining the human experience to which it is an excellent response, and (2) systematically inquiring into the correct specifications for the virtuous response that Filipinos call útang-na-loób. The phrase "correct specification" explicitly signals the normative dimension of the account. Developing an actionguiding virtue-theoretic account that is informed by social scientific research requires that the ensuing account is constrained by the evidence. This means that the ideal way of practicing útang-na-loób can be realized in the complex and 
messy situations that ordinary folk inhabit. An ideal that is unattainable for most because, say, it is not rooted in the economic realities people face must be rejected on the grounds that it is empirically inadequate. There is an important connection between empirical adequacy and judicious use of social scientific research in philosophical theorizing. Such research is precisely what allows us to specify an attainable ideal, use the practice of útang-na-loób in a socially organic manner, and develop effective remedies for existing problems. ${ }^{12}$ This is why I think Filipino philosophers should engage more with work in the social sciences. The account of útang-na-loób that I offer in the next two sections is an illustration of what such an engagement looks like. ${ }^{13}$

Before developing a better philosophical account of útang-na-loób let us look at Nussbaum's discussion of a Marxist objection to virtue. On this objection, neoAristotelians are accused of taking practices such as generosity to be a universal and necessary feature of human life, when it is just a byproduct of contingent historical conditions ("Non-Relative Virtues" 637). Since Marxists take these historical conditions to have non-necessary social features that keep certain groups at a disadvantaged status, virtue theorists are accused of failing to imagine better social conditions in which, say, generosity is no longer required because the institution of private property that deprive many of what they need has been abolished. Hence practices associated with generosity, including debts of good will, are considered "merely bourgeois virtues" and an overall virtue-theoretic approach as something that limits our social aspirations. Marxists then conclude that virtue must be abandoned if we are to undertake a radical reform of social structures that would finally promote the flourishing of all. Nussbaum envisions the Marxist as someone who turns the tables against Aristotelians in an "urge to inquire into the basic structures of human life with the daring of a radical political imagination" ("Non-Relative Virtues" 638). The idea is that Marxists are better committed to the goal of communal flourishing than Aristotelians.

Nussbaum takes the Marxist objection to virtue as "a deep question about human forms of life and the search for the human good" ("Non-Relative Virtues" 643). She thinks that the objection is important for the framework because it requires us to imagine and work towards building radically different forms of life. To relate the point to our current discussion of útang-na-loób, the challenge is to imagine and create a society that no longer includes this practice and has thereby abolished all the problems associated with it. An interesting version of the challenge is to ask whether our interest in believing that útang-na-loób is a Filipino virtue impedes the effort to solve the practical and urgent problems that we saw in the previous section. Nussbaum responds to the Marxist by saying that removing one sort of problem in human society is not the same thing as removing any and all problems associated with excess and deficiency. Since virtues are precisely designed as remedies for 
excesses and deficiencies to which humans are prone, virtues will always be relevant no matter what new socio-political structures we build and imagine. In the case of útang-na-loób, this means that even if we institute social reforms that provide universal access to healthcare, education, and social safety nets, aside from promoting efficient institutions and transparent political processes, we will not succeed in getting rid of all forms of extreme need. Consequently, the benevolent action that responds to such need and creates a debt of good will would also not be abolished. So, there will still be a requirement to be a responsible recipient of other people's benevolence, even in the kind of egalitarian society that Marxists envision.

\section{5. ÚTANG-NA-LOÓB AS A VIRTUE}

In the previous section, we have seen that a neo-Aristotelian framework can be used to develop Filipino virtue ethics in general and útang-na-loób especially in articulating why and how some aspects of the cultural practices can be considered a form of moral excellence while other aspects are vicious or defective. The first step in using Nussbaum's neo-Aristotelian framework to discuss útang-na-loób consists in identifying and describing the shared experience to which this practice is an apt response. Uttang-na-loób arises from the experience of being subjected to extreme need and then being given much needed assistance by another, a benefactor or intermediary, who makes it possible to get something that is beyond one's power to obtain. Being in such a position of helplessness is not unusual for many Filipinos. Typhoons, earthquakes, epidemics, outbreaks of violence, volcanic eruptions, and crop failures periodically subject people to suffering and difficulty. At these times, much-needed help was given by other members of the community. The absence of robust institutions that provide public goods and basic needs means that even in times when there are no calamities, many Filipinos experience extreme need because of illness, accident, or poverty. In such situations, private individuals, civil society groups, and non-governmental organizations intervene to provide the kind of help that millions in the country need. Thus, the experience of being extremely needy and then benefitting from others' goodwill is widespread.

When the much-needed assistance is received in the right way, i.e., virtuously, the initial act of good will begets a desire to give back or to perform a similar act of good will. Consequently, the initial act of good will begets many similar acts and the relationship between individual members of the community is strengthened and the welfare of all is promoted. There are two extremes that are associated with the foregoing practice. First, there is the possibility of being a self-focused recipient of aid who is deficient in responsibility for others. When a person focuses too much on her own neediness she is inclined not to value the benefactor's action. 
This leads to the thinking that one is entitled to other people's generosity and it can mean using one's neediness as an excuse for dependency, relying on others without being responsible for anyone. This means becoming a member of society who is continuously needy, someone who does not exert effort to improve one's situation, other people's lot, or the overall state of one's community. I think this extreme is one that most actively avoid, partly because the invective walâng útang-na-loób still stings for many Filipinos today. ${ }^{14}$ It is noteworthy that since the needy cannot commit an act of good will towards their benefactor or anybody else, without taking care of themselves first, there is an implicit requirement to improve one's own situation as a matter of moral responsibility to oneself and to others. Focusing on this requirement can be used as a corrective against the practically irrational tendency to repay a debt of good will to the point of damaging one's own well-being. Emphasis on a moral obligation to improve one's situation is especially important for those who are underprivileged, like fisherfolk who have no alternative but to resort to onerous fishing partnerships and people in the disadvantaged side of a superordinate-subordinate relationship.

The other extreme is not well-recognized, and it is precisely on this point that philosophical reflection on útang-na-loób can make a contribution. Excessive attention on the benefactor leads many to express útang-na-loób in a misguided way. As we have seen previously, it is not uncommon for Filipinos to vote for candidates to whom they feel beholden or to use útang-na-loób as the sole basis for making important decisions such as awarding lucrative contracts or hiring job applicants. On this extreme, a person loses sight of people apart from the benefactor and the well-being of the greater community. Focusing too much on being indebted towards a particular benefactor and on needing to repay her act of kindness, then leads to a failure to do right by one's responsibility to the community as a whole. The problem consists in damaging relationships with others in the community and failing to uphold everyone's welfare. While it is true that a benefactor's act of kindness creates a special bond between her and the agent, this is not a sufficient reason for failing to act on what will benefit the greater community.

At this juncture, two interrelated Filipino terms are crucial for the practice of útang-na-loób as a virtue. The first is kápuwâ, which importantly includes strangers who do not have any claims on the agent's good will, like the benefactor does. Considering strangers as kápuwâ means taking their well-being into consideration because they still count as an-other(s) who is part of who one is. This means that other people (apart from one's family and benefactor) count as part of the community for whom an agent is responsible. Deliberately disregarding or even damaging the well-being of strangers for the sake of giving back to one's benefactor brings us to the second important term: katarúngan. According to Jose Diokno, Tagalog, Cebuano, Ilonggo, and Kapampangan all feature the word katarúngan, which is not 
exactly equivalent to Western notions of justice. He adds that katarúngan comes from the Visayan word tarong, which means "straight, upright, appropriate, or correct" (18). From the etymology of the word, Diokno concludes that the Filipino conception of justice turns the focus on moral rectitude. This means that moral rectitude should be the basis for what counts as, say, appropriate distribution of goods and opportunities. Diokno observes that even though our core conception of justice is closely associated with moral rectitude, it is not directly connected with what is lawful because the words for justice (katarúngan) and law (batás) are etymologically unrelated (18). It is worth exploring the connection between útang$n a$-loób as a virtue and our native understanding of justice, which is not about what is prescribe-able in statutes of law but about what is appropriate in terms of fairness. At a bare minimum, repaying a debt of good will can only be considered a form of moral excellence if it is sensitive to considerations of fairness, in the sense of not depriving some people of access to resources and opportunities. Providing benefit for one's benefactor while unfairly depriving others of what they need, or should have a chance of attaining, is excessive and unjust. Útang-na-loób is a practice that has a potential for strengthening relationships between members of a community and serving as a mechanism for ensuring that people's needs are met. Indeed, the practice is associated with an element of redistribution. However, great care must be exercised in living out the practice to ensure that redistribution is done in the right way, i.e., in a way that pays special attention to the economically disadvantaged and at the same time promotes the flourishing of the entire community. Without such carefulness, the Marxist objection to virtue cannot be properly addressed. The Marxists are right: we must be willing to imagine a radical possibility in which communal flourishing is promoted because people are not needlessly dependent on those who have more.

In my view, excessive attention to repaying particular benefactors, which comes with a deficiency in being responsible for the greater community, is the extreme to which most Filipinos are inclined. In this section, we have seen that avoiding this extreme and living out útang-na-loób virtuously depends on appreciating our responsibility to others (kápuwâ), especially strangers, and paying close attention to the way that we understand justice (katarúngan). In the next section, we will see a concrete case in which responding to considerations from both utang-naloób and justice leads to acts that can be characterized as a form of affirmative action and repaying one's benefactor in a way that gives back to the rest of the community as well. In keeping with the effort to respond to the Marxist objection to virtue, giving back to the rest of the community must be understood in terms of instituting reforms that promote social justice. 


\section{CASE DISCUSSION ${ }^{15}$}

Let us begin with an example for útang-na-loób that potentially involves the excess to which Filipinos are prone. Reyes provides the following account:

[S]ay I lack money to pay my tuition for a semester in college. A friend hears about my situation and insists that he lend me money rather than postpone my studies. I gratefully accept his offer. After the semester, I save enough money to repay him.... However, I do not consider my utang na loob finished, but I am still open to help him should the opportunity arise. Years later, as professionals, it does come. He loses his job and has difficulties finding another one to support a large family. Being a manager in my own company, I go the extra mile to secure him a good position, pulling some strings along the way. He ends up with a better job than the one he lost. My utang na loob has translated into a significant kagandáhang-loob for him, such that now-given the gravity of his situation-he is the one with an utang-na-loob towards me (Reyes 161; emphasis supplied). ${ }^{16}$

Let us call the narrator in the example, Pedro, and his school friend, Juan. In this example, I am concerned about the specific way in which Pedro goes the extra mile to secure a job for Juan. In other words, what does it mean for Pedro to "go the extra mile" and "pull strings along the way" so that Juan ends up with a better job? Understanding these phrases to include acts that deprive people outside one's ingroup of opportunity, or efforts to manipulate institutions for one's own personal ends, would undermine inclusive communal flourishing. Hence, such courses of action must be rejected, and we must find an alternative way of specifying how útang-na-loób ought to be lived out in this and other similar cases.

There is sometimes an unexamined and empirically unsupported assumption that impartiality or equality and most forms of calculative thinking on distribution are alien to the Filipino mindset. The findings in Alison Carson's research on distributive justice reasoning among Filipinos repudiates this assumption while at the same time shedding light on a distinct way of valuing equality. In her investigation of distributive justice reasoning in two communities in the Philippines, Carson discovered a distinct set of non-Western norms among Filipinos. Most of the participants in Carson's study were shown to have a collectivist orientation, which is consistent with Enriquez's claim that Filipino psychology is kápuwâoriented. The members of urban and rural communities in Carson's study showed a marked preference for two norms of distribution: equality and need. The latter was explained in terms of obligations to needy members of the community and the importance of efficient (or utility-based) distribution, especially in family situations. ${ }^{17}$ Equal distribution of scarce resources was explained in a distinctly Filipino way: hating kapatid (equal sharing among siblings). One participant 
succinctly explains the reasoning behind the equality norm thus: "We are afraid to hurt other people's feelings. So we divide resources equally, everybody gets an equal share regardless of one's status or rank in the community" (Carson 164). ${ }^{18}$ It is worth noting that the thinking expressed here resonates with the principle of equal distribution associated with communism.

Filipinos' concern for promoting equality and helping the needy is characterized by an emphasis on emotion and an acute awareness of how relationships are negatively affected by unequal or unfair distribution of resources. Thus, the ideal communal orientation among Filipinos is nurturing and emotionally sensitive. Such an orientation means that most people have a preference against purely impersonal merit-based distributions, precisely because of the concern to avoid negative emotional consequences arising from unfair distribution and damaging relationships because of a rigidly impersonal attitude towards others. In her research, Carson also notes that Filipinos' preference against a purely merit-based distribution is rooted in of avoidance hurt feelings and promoting social harmony. ${ }^{19}$ This means that the reason for preferring equal or need-based distributions and for not preferring purely merit-based thinking is the same, a desire to promote of social harmony that involves strong positive emotional bonds.

Carson's work has important implications for our understanding of útang-naloób as a virtue. Allocating a scarce resource solely on the basis of having a debt of good will violates Filipinos' sense of fair distribution: it means causing hurt feelings, damaging communal harmony, and negatively affecting efficiency that benefits everyone. If Pedro disregards all other considerations relevant for filling in an important position and gives it to Juan solely on the basis of being indebted to him, then the considerations connected to equality and efficiency are disregarded. Setting aside equality would damage relationships and cause deep divisions in a professional network that depends on social harmony. Considerations related to efficiency are not satisfied because we know little or nothing about whether Juan would perform the job in the best possible way for the benefit of everyone. The latter is connected to equity or merit since the person who is most qualified for the job is most likely the one who will perform very well. Most important of all, moral rectitude (katarúngan) is disregarded because not all interested parties were given the same opportunity to earn a coveted opportunity.

Pedro is not obliged to do anything and everything possible, including to commit illicit actions, to secure a job for Juan. Expending professional and financial capital to influence or manipulate powerful people in his professional network is questionable at best. Ensuring that other qualified candidates are not even considered for the position is unfair. And it is dishonest to recommend Juan enthusiastically to the people who will make the hiring decision without telling 
them that he is an old school friend and benefactor. Nevertheless, Pedro must do a lot of things to help Juan find a new job. He must make sure that Juan hears about all relevant job openings and that he gets needed information and preparation for applying to these positions. If Juan does not get a job that he applies for, it is part of Pedro's responsibility to continue to help him. What counts as generous repayment of the debt of good will is to continue helping him until he no longer needs help from others. This is the kind of help that Pedro initially received in the form of a loan. ${ }^{20}$ And this is the kind of help that mothers ideally give to their helpless children.

What matters is for Pedro to help Juan find the best professional situation for himself after he got laid off. The point is not for Pedro to position himself as his friend's savior, to beat Juan in a game of one-upmanship, or for Pedro to boast that it was he who got a new and better job for his friend. Avoiding these pitfalls is crucial for the flourishing of the entire community. And since the focus is also turned on this community, instead of just on a specific individual, Pedro and Juan must both work toward a situation in which workers are not unjustly laid off late in their careers and that substantial safety nets are kept in place so that people who suddenly lose their jobs can find new ways to support themselves. The idea here is not different from beneficiaries of scholarships being themselves benefactors to needy students.

There is an important sense in which recognizing and repaying debts of goodwill is about giving back to the community and creating opportunities for everyone, especially the needy, to improve their lives. To recall an idea from Miranda, the point of doing an act of good will is to ensure that people who were once needy, like Pedro and Juan, to acquire maternal-life-giving-responsibility for others so that they nurture growth and flourishing in the community. Being clear about the connection between útang-na-loób and justice (katarúngan) allows us to say that such maternal responsibility and nurturance of growth necessarily involve building just institutions and introducing social reform that is oriented towards inclusivity and equal distribution of resources. Coincidentally, some women in Philippine history embody the kind of maternal care and social concern that we have just been describing. Melchora Aquino, who was fondly called Tandang Sora, is recognized as the Mother of the Philippine revolution precisely because she provided much needed material support to Bonifacio and other revolutionaries despite great economic cost and significant risk to her personal safety (Ocampo). She embodied virtuous giving and involvement in the radical reform of society. Recognizing Tandang Sora, and others like her, as an exemplar of good will and responsible giving back allows us to appreciate that behaving virtuously means not being confined by dyadic relationships between benefactors and beneficiaries. Arguably, her generosity and good will are rooted in the recognition that she and 
all other Filipinos owe a debt of good will to the revolutionaries. In focusing on this point, we would be more conscious of the broader scope of our responsibility when we act out of útang-na-loób; this practice involves making an ample return to benefactors while at the same time contributing to the effort to build a better future for all.

In conclusion, útang-na-loób is a Filipino virtue that should be practiced in conjunction with justice (katarúngan). Generously repaying a debt of good will would only contribute to inclusive communal flourishing if it is done in a way that satisfies the demands of justice and the requirement to promote social reform or public policy that benefits the least well-off members of society. In so doing, a communal orientation that is both inclusive and nurturing would be promoted in a distinctly Filipino way. Moving forward, our effort to develop philosophical accounts of útang-na-loób and other Filipino virtues should proceed in an empirically grounded and practical way. And if the points that I raised in the case discussion are correct, then developing Filipino virtues in this way enables us to rehabilitate and give prominence to the role of exemplary women in our society. In the current political climate, this can only be a good thing. 


\section{Acknowledgement}

Research for this paper is supported by an Ateneo de Manila University Loyola Schools Scholarly Work Faculty Grant (2016). For critical comments on earlier drafts, I would like to thank Noel Clemente and two anonymous referees for Kritika Kultura. 


\section{Notes}

1. Emerita Quito notes that Filipino traits and values, including útang-na-loób, are ambivalent in the sense that they have both negative and positive characteristics. Interestingly, Quito's discussion begins from the idea that Filipino traits and values are mostly negative. Part of her work consists in identifying the positive side of such traits and values. She says that the positive side of útang-na-loób consists in the proper recognition of indebtedness. Quito associates útang-naloób with the proverb "Ang hindî marúnong lumingón sa pinanggálingan, hindî makakarating sa paroroónan" ["He who does not know how to look to the past will never reach his destination."] (6o, Quito's translation). Francis Dancel, who associates útang-na-loób with gratitude, also concludes that it is difficult to say whether útang-na-loób morally desirable or not (124).

2. Developing empirically grounded philosophical theories in general and accounts of virtue in particular are associated with a movement called empirical and experimental philosophy. Mark Alfano, Don Loeb, and Alexandria Plakias provide an illuminating account of this movement: "the guiding principle of experimental philosophy is that when philosophical arguments invoke or make assumptions about empirical matters, those assumptions should be assessed according to the best natural and social scientific evidence available, and that if such evidence is not currently available it should where possible be acquired, either by seeking the help of specialists with the relevant scientific training or by having well-trained philosophers conduct the research themselves. Thus, the term 'experimental moral philosophy' might be replaced by a phrase like empirically well-informed moral philosophy." In what follows, my effort to develop a new account of útang$n a-l o o ́ b$ is informed by this empirically grounded approach.

3. This characterization of an excellent response to fear comes from Nussbaum's neo-Aristotelian framework, more on this in section four. She discusses the cultural variability of human experiences such as fear and bodily appetite to show how a neo-Aristotelian framework can address questions on what counts as a form of excellence even if there is no singular definitive way of having these experiences. She takes the historical and genealogical approach used by Michel Foucault, especially in the History of Sexuality, as something that is useful to loosen the grip of our culture on our minds so we can begin to imagine forms of moral excellence that are more inclusive. Nussbaum also argues that the neoAristotelian framework allows us to say accept multiple and incommensurable forms of excellence while at the same time allowing for a principled exclusion of morally undesirable practices (or forms of it).

4. Interestingly, even some older Filipino philosophers refer to the characteristics of útang-na-loób similar to those enumerated by de Castro (Mercado 101-102).

5. In his pioneering work, Enriquez identified kápuwâ (another who is part of oneself) as the central concept in indigenous Filipino psychology. Conceiving of

Kritika Kultura 33/34 (2019/2020): 175-179

(C) Ateneo de Manila University

<http://journals.ateneo.edu/ojs/kk/> 
another as part of oneself gives rise to a non-individualistic conception of selfhood such that unity or oneness with others becomes a natural final goal.

6. The latter is probably incomprehensible to those who are unfamiliar with the realities in public hospitals and charity wards in Manila, where it is possible to get $\mathrm{x}$-rays, blood and other tests for free or at very low rates. But without knowing whom to ask, what forms to fill, which individuals or offices to approach, etc., people cannot benefit from these provisions.

7. De Castro, a philosopher, and Kaut, a social scientist, agree on this point.

8. Nussbaum endorses a view that she calls Aristotelian essentialism, which she takes to be pluralist and necessary for the constructive criticism of social norms ("Human Functioning and Social Justice"). On this view, a social norm that disallows equal access to the economic resources of the community on the basis of gender can be criticized on the basis of violating a requirement essential for human functioning, namely, basic economic rights. I neither endorse nor presuppose Nussbaum's essentialism. My discussion only depends on two beliefs that are associated with her view: (a) there are empirical constraints on what moralities allow for communal flourishing that is consistent with pluralism; and (b) there is no single true morality. These two beliefs do not necessarily imply essentialism of any sort. The use of the terms "objective" and "correct" in what follows refers to the empirical constraints associated with (a). Interestingly, (a)(b) are also prominent features of moral relativism defended and developed by David B. Wong, who also adopts a virtue-theoretic approach. My own metaethical predilections are more closely aligned with Wong's views than with Nussbaum's. It is beyond the scope of this paper to provide arguments for such views.

9. As explained previously, this point is compatible with the belief that there is no single true morality. There is a need to emphasize constraints on what counts as morally desirable even in pluralist, relativist, or irrealist metaethical theories because without such constraints it is virtually impossible to say that moralities that forbid systematic oppression of certain groups are better than those that allow it. While it does not neatly fit under the theories just mentioned, Marxist philosophy is a good example of a framework that provides a basis for clearly judging whether a practice is morally acceptable without necessarily being committed to the belief that there is a single overarching set of rules that objectively grounds morality.

10. The uncritical reliance on the intuitions and armchair speculations of philosophers has been shown to be (mostly) misguided by those working in experimental philosophy.

11. Nussbaum does not specifically refer to using social science literature, much less use it following the lead of philosophers who do experimental philosophy. Doing the latter is part of my contribution in this paper.

12. I say more about empirical grounded methodology elsewhere (see Cleofas).

13. Apart from engagement, there might even be collaboration between philosophers and social scientists on applied research, especially on topics connected to the promotion of inclusive and communal flourishing.

Kritika Kultura 33/34 (2019/2020): 176-179

(C) Ateneo de Manila University

<http://journals.ateneo.edu/ojs/kk/> 
14. This phrase literally means having no debt of good will; it signals disapproval of someone who refuses to acknowledge and/or repay another's generosity.

15. The method that I use for this section is compatible with the one used by Alora and Lumitao in their volume on a non-Western and distinctly Filipino approach to bioethics.

16. Reyes himself does not characterize this example as potentially problematic.

17. Within the family, it makes sense to allocate a scarce resource to the neediest member because taking care of such a person has a very significant impact on the well-being of the entire family.

18. The strong preference for equal distribution out of an effort to avoid the emotional consequences of unequal distribution is so deeply ingrained that it is evident in Filipino children as young as 10-12 (Carson and Banuazizi).

19. Merit or equity-based distribution is the preferred norm for individualistic cultures such those found in the United States.

20. He would not have graduated on time without this loan. But it was Pedro himself who worked hard to manage his course requirements, etc.

Kritika Kultura 33/34 (2019/2020): 177-179

(C) Ateneo de Manila University

<http://journals.ateneo.edu/ojs/kk/> 


\section{Works Cited}

Alfano, Mark, Don Loeb, and Alexandria Plakias. Experimental Moral Philosophy. The Stanford Encyclopedia of Philosophy, edited by Edward N. Zalta, 9 Aug. 2018, http:// plato.stanford.edu/archives/sum2016/entries/experimental-moral/. Accessed 9 August 2016.

Alora, Angeles Tan, and Josephine M. Lumitao, editors. Beyond a Western Bioethics: Voices from the Developing World. Georgetown UP, 2001.

Carson, Alison Stettinius. "Distributive Justice Reasoning in Two Communities in the Philippines." Boston College Dissertations and Theses. 2000.

Carson, Alison S., and Ali Banuazizi. “'That's Not Fair' Similarities and Differences in Distributive Justice Reasoning between American and Filipino Children." Journal of Cross-Cultural Psychology, vol. 39, no. 4, 2008, pp. 493-514.

Cleofas, Jacklyn. "An Understanding of Character from Holistic Thinking: What Asian Psychology Teaches us about the Debate on Situationism." Frontiers of Philosophy in China (forthcoming).

Dancel, Francis. "Utang na Loob [Debt of Goodwill]: A Philosophical Analysis. Filipino Cultural Traits: Claro R. Ceniza Lectures, edited by Rolando M. Gripaldo, The Council for Research in Values and Philosophy, 2005, pp. 109-128.

De Castro, Leonardo D. "Debts of Good Will and Interpersonal Justice." Boston University, 1998, https://www.bu.edu/wcp/Papers/Asia/AsiaDeCa.htm. Accessed 29 June 2017.

-.. "Kagandahang Loob: A Filipino Concept of Feminine Bioethics." Globalizing Feminist Bioethics, edited by Rosemarie Tong, Westview Press, 200o, pp. 51-61.

Diokno, Jose W. A Nation for Our Children: Selected Writings of Jose W. Diokno, edited by Priscilla S. Manalang, Claretian Publications, 1987.

Enriquez, Virgilio G. "Kapwa: a Core Concept in Filipino Social Psychology." Philippine Journal of Social Psychology, vol. 10, no. 1, 1978, pp. 3-18.

Guthrie, George M. “The Philippine Temperament." Six Perspectives on the Philippines, Bookmark, 1968, pp. 49-83.

Hollnsteiner, Mary R. "Reciprocity in the Lowland Philippines." Four Readings on Philippine Values, edited by Frank Lynch and Alfonso de Guzman II, Ateneo de Manila UP, 1973, pp. 69-118.

Kaut, Charles R. "Utang na Loob: A System of Contractual Obligations Among Tagalogs." Southwestern Journal of Anthropology, vol. 17, no. 3, 1961, pp. 256-272.

Mercado, Leonardo N. Filipino Thought. Logos Publications, 2000.

Miranda, Dionisio M. Pagkamakatao: Reflections on the Theological Virtues in the Philippine Context. Divine World Publications, 1987.

Nussbaum, Martha C. "Non-Relative Virtues: An Aristotelian Approach." Ethical Theory: An Anthology, edited by Russ Shafer-Landau, John Wiley \& Sons, 2013, pp. 63-644. Originally published in Midwest Studies in Philosophy, vol. 13, 1988, pp. 32-50.

-.. "Human Functioning and Social Justice: In Defense of Aristotelian Essentialism." Political Theory, vol. 20, no. 2, 1992, pp. 202-246. 
Ocampo, Ambeth. "Tandang Sora Home on Her $200^{\text {th }}$ Birthday." Philippine Daily Inquirer, 5 Jan. 2012, https://opinion.inquirer.net/20595/tandang-sora-home-on-her-2oothbirthday. Accessed 11 Dec. 2018.

Quito, Emerita. "The Ambivalence of Filipino Traits and Values." Values in Philippine Culture and Education, edited by Manuel B. Dy, Jr., The Council of Research in Values and Philosophy, 1994, pp. 57-62.

Reyes, Jeremiah. "Loób and Kapwa: An Introduction to Filipino Virtue Ethics." Asian Philosophy, vol. 25, no. 2, 2015, pp. 148-171.

Wong, David B. Natural Moralities: A Defense of Pluralistic Relativism. Oxford UP, 2009. 